\title{
Book Review: Julie Fette, Exclusions: Practicing Prejudice in French Law and Medicine 1920-1945, Ithaca and London: Cornell University Press, 2012. Pp. 328. \$49.95 (ISBN 978-0-8014-5021-1)- CORRIGENDUM
}

\section{LIORA ISRAËL}

doi: 10.1017/S073824801300076X, Published by Cambridge University Press, $6^{\text {th }}$ February, 2014.

The book review originally lists the book's author as "Juliette Fette."

The author regrets the error.

\section{REFERENCE}

Liora Israël (2014). Book Review: Julie Fette, Exclusions: Practicing Prejudice in French Law and Medicine 1920-1945, Ithaca and London: Cornell University Press, 2012. Pp. 328. \$49.95 (ISBN 978-0-8014-5021-1)CORRIGENDUM 